DOI: $10.31866 / 2410-1915.22 .2021 .235903$

UDC 004.8:75

\title{
ARTIFICIAL INTELLIGENCE AND ISSUE OF AUTHORSHIP AND UNIQUENESS FOR WORKS OF ART (TECHNOLOGICAL RESEARCH OF THE NEXT REMBRANDT)
}

\section{Tetiana Sovhyra}

PhD in Art Studies,

ORCID: 0000-0002-7023-5361, STIsovgyra@gmail.com, Kyiv National University of Culture and Arts, 36, Ye. Konovaltsia St., Kyiv, 01133, Ukraine

\section{For citations:}

Sovhyra, T. (2021). Artificial Intelligence and Issue of Authorship and Uniqueness for Works of Art (Technological Research of the Next Rembrandt). Culture and Arts in the Modern World, 22, 156-163. https://doi.org/10.31866/2410-1915.22.2021.235903.

The purpose of the article is to explore the specifics and uniqueness of visual works created using AI technology. The research methodology is based on applying analytical, theoretical, and conceptual research methods of technological art and the interrelation between digital technologies and art in general. The scientific novelty lies in the fact that the art forms that created using digital technologies were analysed for the first time. In the article, we have considered the phenomenon of technological art due to integrating art and technology. Conclusions. It is revealed that due to the mathematical analysis of the artists' artworks, certain algorithms of the author's work can be found, the main components of the work of art can be analysed, and the sign system of art can be transformed into a system of a different order which is numerical one. Thus, the colour, shape, positioning of the objects on the canvas (composition) - everything turns into numerical formulas and combinations. The graphic drawing is transformed into digital, algorithmic. A certain number system is being built, which allows to group works (one artist, era, art movement) into single collection systems, analyse and identify similar algorithmic chains, and create new art products based on these algorithms using the obtained numerical combinations. It means that with algorithmic analysis, it is possible to compare and even combine different types of art within one plane, one form, and one art product.

Keywords: AI-technology; painting; algorithm; digital painting; 3D-printing

\section{Introduction}

A hypothetical theory of technological singularity appears in the mirror of scientific criticism (Good, 1966; Moore, 1975). According to supporters of the "techno-singularity" concept, the generation of artificial intelligence and cyber machines will lead to the improvement of the technical and technological production component (machines can self-repair, perform certain manip-

(C) Tetiana Sovhyra, 2021

The article was received by the editorial office: 19.02 .2021 
ulations faster and better than human activities) (Vinge, 1993). Today we can observe how artificial intelligence is several times superior to humans in the speed of computing, moving, productivity, etc.

The same goes for art. With the help of digital technologies, it is now possible to scan and create electronic versions of graphic works, produce copies of famous canvases, save and archive artefact data, and even create unique authorial paintings.

In recent years, significant historical, cultural and theoretical works have been published, where attention is paid to the history of cybernetic art as the forerunner of digital culture of the late twentieth century. Among them are publications by V. Glushkov (1986), M. Lovejoy (2004), F. Popper (2007), D. Galkin (2013).

G. Franke (1971), D. Galkin (2013) and M. Lovejoj (2004) examine the concept of "digital culture" and explore the features of hybridisation of technology and art.

In the works of Ts. Kogoutek (1976), V. Shcheglov (2016, 2017), the relationship of digital technologies and art is studied. V. Shcheglov indicates a series of repeating sequences in the context of artistic content in the "Painting of the $20^{\text {th }}$ Century: Fundamentals of Algorithmic Interpretation" (2017) and "Poetry: Fundamentals of Algorithmic Interpretation" (2016) on the example of poetry and painting. The author calls them algorithms, and therefore, poetry and painting are algorithmic systems.

However, despite the public interest in technological art, there is a lack of scientific justification for the possible interaction of technology and art in general and a critical analysis of the specifics of the functioning of technological art.

\section{Purpose of the article}

The purpose of the study is to analyse the forms of interaction of modern technologies and various types of art, to identify such art forms that can be organised (created) exclusively through digital (or other) technologies.

\section{Main research material}

The Next Rembrandt is a portrait painting that reproduces Rembrandt's creative style with exceptional accuracy, but it is not a copy of the image of the master's paintings. It became possible due to the technologies of "Artificial Intelligence". Specialists from Microsoft, the University of Delft Technical University, the Royal Mauritshuis Gallery and the Rembrandt House Museum in Amsterdam, using Microsoft Azure computing resources and a number of specialised algorithms, performed a three-dimensional scan of 346 artist's paintings and discovered not an only genre and stylistic specifics, but also techniques specific to the artist and oil painting techniques. 


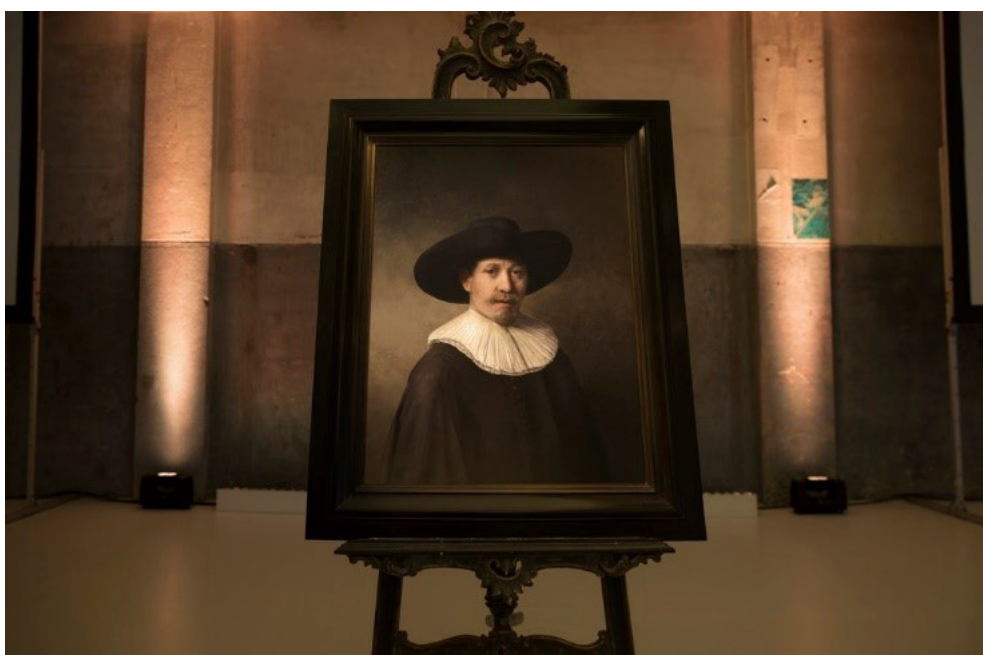

Figure 1. The Next Rembrandt, 2016. Creators: ING Bank, J. Walter Thompson Amsterdam, Microsoft, TU Delft, Mauritshuis, etc.

The Next Rembrandt is a 3D-printed picture created in 2016. The process of creating the canvas was highly complex and lengthy. About twenty data analysts, developers, professors in artificial intelligence and 3D printing, scientists, engineers and art historians worked on the project ${ }^{1}$.

Studing the context of The Next Rembrandt reproduction, the question of authorship arises. Who is the author and performer of this product? Is it possible to determine this picture as an artwork or a technological experiment and nothing besides?

Opinions of scientists and critics differ in identifying the author of this work. Mark Brown believes that "the real creators of the picture are data analysts and computers” (Brown, 2016).

The leading developer of the project, Bas Korsten (J. Walter Thompson, Amsterdam), says that the author of the work is Rembrandt himself because the project is based on an analysis of the artist's work. "The Next Rembrandt really touched the nerve. This raised all sorts of questions about creativity ... We are creating something new from his work. Only Rembrandt could create Rembrandt" (O’Neill \& Corner, 2016).

As a result of the literature review, certain contradictions arise regarding authorship's definition and the importance of artificial intelligence technology in the project.

To study these issues, we consider in detail the process of creating The Next Rembrandt.

\footnotetext{
1 Executive Creative Director: Bas Korsten; Concept: Bas Korsten, Robert Nelk, Mark Peeters; Creative copy: Bas Korsten, Kasia Haupt Canning; Creative art: Guney Soykan; Innovation Director: Emmanuel Flores; Design: Vinesh Gayadin; Digital Director: Jesse Houweling; PR Director: Jessica Hartley; Editor: Tim Arnold; Photography: Robert Harrison; Developers: Morris Franken, Ben Haanstra (Pickett-Groen, 2016).
} 
The immediate process of creating the work was preceded by an analysis of the existing paintings of the master and the identification of patterns in the combination of colours, applying strokes and compositional image construction.

The complete collection of images includes 346 paintings by Rembrandt; most of them look highly realistic. There are several explanations for this. Rembrandt, using the play of light and shadow, created unique picturesque compositions that looked very realistic and voluminous. As a result of these manipulations in his work, there is a desire for accuracy and truthfulness. The master prefers psychological expressiveness instead of violent pathos and external effects. "The main formative element of the composition, which allowed the artist to fully materialise and convey to the viewer his own plan - chiaroscuro, or rather, the scheme of alternating spots of light and shadow that he constructed with mathematical precision" (Tarasov, 2014).

The artworks provided by TU Delft and the Mauritshuis Museum were scanned in high resolution (The Laughing Man, 1629-1630; Andromeda, 1630; Simeon's Song of Praise, 1631; The Anatomy Lesson of Dr. Nicolaes Tulp, 1632; Susanna, 1636; Saul and David, 1651-1658; Two African Men, 1661; Homer, 1663; 'Tronie' of a Man with a Feathered Beret, 1635-1640; Portrait of an Elderly Man, 1667; Rembrandt van Rijn, Self-Portrait, 1669) ("Rembrandt", n.d.).

The remaining works were taken from other archival sources. Thus, all images' resolution was different and incompatible, which was a problem for systematising and identifying the necessary image similarity algorithms. To solve this problem, the team used the Deep Neural Network algorithm to scale images, increasing resolution by 300\% and reducing visual noise (Pickett-Groen, 2018).

Further, the authors of the project had to decide on the planned picture's content: the depicted object and the canvas's composition. For this, more than 400 faces were examined on Rembrandt's canvases, after which it became clear that the subject should be from 30 to 40 years old. The master most often depicted males in his works, so The Next Rembrandt is a man in a black hat, a black jacket with a white collar.

It was necessary exactly with the technique of the master to depict the face of this man. For this, developers needed Microsoft software that could "understand" Rembrandt based on his geometry and composition. As a result of using the face recognition algorithm, typical geometric patterns used to draw human features were identified. More than 6,000 facial landmarks were used to classify features in terms of relevance and repeatability.

The third stage of The Next Rembrandt production was the preparation for printing the created image and the identification of a specific technology for applying paint. As known, Rembrandt van Rijn revolutionised painting with a three-dimensional effect using the impasto technique - applying paint to the canvas with very thick layers. As a result, his canvases looked three-dimensional. To create a picture that would resemble the artist's work, it was necessary to study the impasto technique and, thanks to X-ray photographs, examine each layer of the existing paintings. After that, the future The Next Rembrandt image needed to add another dimension, 2D to 3D. The final layout of the 3D painting 
consists of more than 148 million pixels and is based on 168,263 fragments of the Rembrandt painting.

The fourth stage was printing. At first, the developers used the manipulator to paint a new portrait. But the robot arm could not convey the desired realistic effect. The manipulator has only nine degrees of freedom. Instead, the human hand has 26, which meant that it still could not draw in great detail.

Since the digital image was already voluminous, it was necessary to print 13 layers of special ink based on UV ink on a 3D printer Canon. Thus, the image became three-dimensional.

The fifth stage of creating the project is the presentation and use of The Next Rembrandt canvas. As known, after the presentation in the Netherlands, the project was presented in many cities. Note that the original version of the image is in electronic form so that the image can be replicated numerously.

It is well known that in the art using artificial intelligence, copies of the works of famous artists, composers, architects and representatives of other creative industries are created. Therefore, artificial intelligence is not only the technical embodiment of human thinking but also creativity now.

Using artificial intelligence technology, visual works began to be produced that have no analogues and are not copies of known works.

Now AI-technologies create art products based on algorithmic analysis of already created fine masterpieces. Based on aforesaid, we offer our own definition of "algorithmic art". It is the production process of art products created on the basis of algorithmic analysis of primary information sources. The primary sources are works of art, artefacts, the works of artists of various art types.

However, this practice is not solitary. Other forms of art in the early stages of their formation also borrowed the specifics of creating works from their predecessors. Cinema is based on theatre art, the theatre, in turn, is a synthesis of literature, music, plastic; television is the result of the synthesis of cinema and radio. Therefore, we can state that digital algorithmic art is at the first stage of its development and has significant prospects for its development.

An example of The Next Rembrandt shows that technological singularity in art is entirely possible. But we do not exclude the uniqueness of human activity and artistic creation. Besides, we emphasise the need to develop the symbiosis between man and digital technologies in art: a combination of the capabilities of "artificial intelligence" and people's aesthetic sensitivity.

In Rembrandt's works there is a desire for technological experiments. He used the then-unknown in art practice mineral plumbonacrite in paint recipes. Scientists have revealed that the master created his self-portraits using a mirror system (O'Neill \& Corner, 2016). The use of these technologies does not diminish the significance of Rembrandt's work in the history of fine art. Perhaps if AI technology were invented in the $17^{\text {th }}$ century, the master would create a realistic image. These assumptions give reason to consider artificial intelligence technology only as a tool with which a modern artist can create. In this case, the author will be the creator himself, the artist. Considering that 20 data analysts, developers, professors in the field of artificial intelligence and 3D printing, scientists, engineers and art historians from organisations such 
as Microsoft, Delft University of Technology, Mauritshuis in The Hague and the Rembrandt House Museum in Amsterdam worked on The Next Rembrandt project, the collective mind means the author.

\section{Conclusions}

As in the case of The Next Rembrandt pre-production, it is demonstrated that thanks to the mathematical analysis of the artist's work, it is possible to find specific algorithms for the artist's work, analyse the main components of the work of art and turn the semiotic system of art into a system of a different order as numerical one. At the same time, a numerical algorithmic work, reproducing the artist's lead pencil with exceptional accuracy, can be original work, never a copy; that is, with the help of AI technology, one can create a unique artistic product. It can imitate the painting style of a famous artist, but it has its own content.

Coping of visual and musical works using AI technology is already somewhat common in the modern world. Indeed, creating original visual works that know no equals and are not copies of works of art is the next step in identifying the creative application of AI tools' options.

It is emphasised that technology is only a tool in humans' hands, including artificial intelligence, which does not replace humans since AI technology creates art objects based on algorithmic analysis of existing masterpieces.

Our own definition of the concept of "algorithmic art" is proposed. It is the process of production of art objects, built upon the algorithmic analysis of primary sources of information such as works of art, artefacts, works of artists of various types of art.

\section{References}

Brown, M. (2016, April 5). New Rembrandt to be Unveiled in Amsterdam. The Guardian. https://www.theguardian.com/artanddesign/2016/apr/05/new-rembrandt-to-beunveiled-in-amsterdam [in English].

Franke, H. W. (1971). Computergraphik-Computerkunst. Bruckmann [in German].

Galkin, D. V. (2013). Ot vdokhnoveniya mashinami k iskusstvennoi zhizni: etapy razvitiya tekhnologicheskogo iskusstva [From inspiration by machines to artificial life: stages in the development of technological art]. Bulletin of Tomsk State University Cultural Studies and Art Studies, 1(9), 44-51 [in Russian].

Glushkov, V. M. (1986). Kibernetika. Voprosy teorii i praktiki [Cybernetics. Questions of Theory and Practice]. Nauka [in Russian].

Good, I. J. (1966). Speculations Concerning the First Ultraintelligence Machine. Advances in Computers, 6, 31-88. https://doi.org/10.1016/S0065-2458(08)60418-0 [in English].

Kogoutek, Ts. (1976). Tekhnika kompozitsii v muzyke XX veka [Technique of Composition in Music of the 20th Century]. Muzyka [in Russian].

Lovejoy, M. (2004). Digital Currents: Art in the Electronic Age. Routledge [in English].

Moore, G. (1975). Progress in Digital Integrated Electronics. International Electron Devices Meeting, IEEE, 11-13 [in English]. 
O’Neill, F., \& Corner, S. P. (2016). Rembrandt's Self-Portraits. Journal of Optics, 18(8). https://doi.org/10.1088/2040-8978/18/8/080401 [in English].

Pickett-Groen, N. (2018, January 24). The Next Rembrandt: Bringing the Old Master Back to Life. Case Study: Behind the Scenes of Digital Design. Dutch Digital Design. https:// medium.com/@DutchDigital/the-next-rembrandt-bringing-the-old-masterback-to-life-35dfb1653597 [in English].

Popper, F. (2007). From Technological to Virtual Art. MIT Press [in English].

Rembrandt. (n.d.). Mauritshuis. Retrieved March 1, 2021, from https://www.mauritshuis. nl/en/explore/the-collection/rembrandt [in English].

Shcheglov, V. N. (2016, September 18). Poeziya: osnovy algoritmicheskoi interpretatsii [Poetry: Fundamentals of Algorithmic Interpretation]. https://shcheglov. livejournal.com/30538.html [in Russian].

Shcheglov, V. N. (2017, January 22). Zhivopis’XX veka: osnovy algoritmicheskoi interpretatsii [Painting of the 20 ${ }^{\text {th }}$ Century: the Basics of Algorithmic Interpretation]. https:// shcheglov.livejournal.com/31914.html [in Russian].

Tarasov, Yu. A. (2014). "Nochnoi dozor" Rembrandta - kul'minatsiya v razvitii zhanra gollandskogo gruppovogo portreta XVII veka ["Night Watch" by Rembrandt - the Culmination in the Development of the Genre of the Dutch Group Portrait of the $17^{\text {th }}$ Century]. Bulletin of St. Petersburg University. Series 2: History, 1, 114-122 [in Russian]. Vinge, V. (1993, March 30-31). The Coming Technological Singularity: How to Survive in the Post-Human Era. In Vision-21: Interdisciplinary Science and Engineering in the Era of Cyberspace, Proceedings of a Symposium (pp. 11-22). National Aeronautics and Space Administration [in English].

\section{ШТУЧНИЙ ІНТЕЛЕКТ ТА ПИТАННЯ АВТОРСТВА І УНІКАЛЬНОСТІ МИСТЕЦЬКИХ ТВОРІВ (ТЕХНОЛОГІЧНЕ ДОСЛІДЖЕННЯ РОБОТИ «НАСТУПНИЙ РЕМБРАНДТ»)}

\section{Тетяна Ігорівна Совгира}

\section{Кандидат мистецтвознавства,}

ORCID: 0000-0002-7023-5361,STIsovgyra@gmail.com,

Київський національний університет культури і мистецтв, Київ, Україна

Мета статті - дослідити специфіку та унікальність візуальних робіт створених за допомогою АІ-технологій. Методологія розвідки грунтується на застосуванні аналітичного, теоретичного і концептуального методів дослідження технологічного мистецтва і взаємозв'язку цифрових технологій і мистецтва у цілому. Наукова новизна полягає в тому, що вперше були проаналізовані форми мистецтва, створені з використанням цифрових технологій. Розглянуто феномен технологічного мистецтва як результат інтеграції мистецтва і технологій. Висновки. Виявлено, що за допомогою математичного аналізу творчості художників можливо отримати певні алгоритми роботи автора, проаналізувати основні складові художнього твору, знакову систему мистецтва 
трансформувати в систему іншого порядку - числового. Таким чином, колір, форма, розташування об’єктів, що відображаються на полотні (композиція), - все перетворюється на числові формули та комбінації. Графічний малюнок трансформується у цифровий, алгоритмічний. Будується певна система обчислення, яка дозволяє за допомогою отриманих числових комбінацій групувати роботи (один художник, епоха, художній напрям) в єдину систему колекцій, аналізувати та ідентифікувати схожі алгоритмічні ланцюжки і створювати нові художні продукти на основі цих алгоритмів. Це означає, що за допомогою алгоритмічного аналізу можна порівнювати і навіть комбінувати різні види мистецтва в одній площині, в одній формі, в одному художньому творі.

Ключові слова: AI-технологія; живопис; алгоритм; цифровий живопис; 3D-друк

\section{ИСКУССТВЕННЫЙ ИНТЕЛЛЕКТ И ВОПРОС АВТОРСТВА И УНИКАЛЬНОСТИ ХУДОЖЕСТВЕННЫХ ПРОИЗВЕДЕНИЙ (ТЕХНОЛОГИЧЕСКОЕ ИССЛЕДОВАНИЕ ПРОИЗВЕДЕНИЯ «СЛЕДУЮЩИЙ РЕМБРАНТ»)}

\section{Татьяна Игоревна Совгира}

Кандидат искусствоведения, ORCID: 0000-0002-7023-5361, STIsovgyra@gmail.com, Киевский национальный университет культуры и искусств, Киев, Украина

Цель статьи - исследовать специфику и уникальность визуальных работ, созданых с помощью АІ-технологий. Методология исследования основана на применении аналитических, теоретических и концептуальных методов исследования технологического искусства и взаимосвязи цифровых технологий и искусства в целом. Научная новизна заключается в том, что впервые были проанализированы формы искусства, созданные с использованием цифровых технологий. Рассмотрен феномен технологического искусства как результата интеграции искусства и технологий. Выводы. Выявлено, что с помощью математического анализа творчества художников можно найти определенные алгоритмы работы автора, проанализировать основные составляющие художественного произведения, а знаковую систему искусства трансформировать в систему другого порядка - числового. Таким образом, цвет, форма, расположение отображаемых объектов на холсте (композиция) - все превращается в числовые формулы и комбинации. Графический рисунок трансформируется в цифровой, алгоритмический. Строится определенная система счисления, которая позволяет с помощью полученных числовых комбинаций группировать работы (один художник, эпоха, художественное направление) в единую систему коллекций, анализировать и идентифицировать похожие алгоритмические цепочки и создавать новые художественные продукты на основе этих алгоритмов. Это означает, что с помощью алгоритмического анализа можно сравнивать и даже комбинировать разные виды искусства в одной плоскости, в одной форме, в одном художественном произведении.

Ключевые слова: AІ-технология; живопись; алгоритм; цифровая живопись; 3D-печать 